\title{
Creating A Cause For Sustainability: A Practice-Based Research Project For Undergraduate Students
}

Christopher N. Doval, Virginia State University, USA

Cary A. Caro, Xavier University of Louisiana, USA

\begin{abstract}
Corporate social responsibility (CSR) and corporate sustainability (CS) practices have an influence on the image and profitability of any business. As business schools attempt to mold future leaders, schools have found exploring the topic of CSR and CS into their business curriculum. While many theoretical approaches have been taken, there are few examples of practical projects that professors can utilize in the classroom. Here, the authors present an example of a semester-long project that forces students to examine and reflect upon their own personal consumption habits and create a "personal" CSR report. The authors describe the project, expected outcomes, and the narratives that are created in the project and the course. Finally, the paper examines the importance of personal reflection on the development of personal cause and responsibility, which can help to develop future socially responsible leaders.
\end{abstract}

Keywords: Corporate Social Responsibility (CSR); Corporate Sustainability (CS); Sustainability

\section{INTRODUCTION}

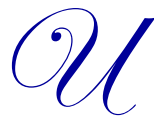
ndergraduate business programs face increased pressure from industry to produce educated graduates, prepared with the practical knowledge and skills that allow them to be integral parts of organizations at the onset of their business careers. Concomitantly, the leading academic accrediting body for business schools has challenged global programs to promote ethics and corporate social responsibility in their curriculums, adding, "The time has come for business schools to renew and revitalize their commitment to the centrality of ethical responsibility at both the individual and corporate levels in preparing business leaders for the twenty-first century" (AACSB International, 2004, p. 9). While many programs may have responded to this call by the AACSB, Bridges and Wilhelm (2008) and Matten and Moon (2004) report that most of the efforts to teach CSR and sustainability have been focused on the graduate level of education. Further, the practice at the undergraduate level appears to be limited by the lack of coverage in business text books (Demoss \& Nicholson, 2005).

Here, the authors introduce a practical and interactive method for introducing CSR and sustainability to the undergraduate classroom. We will describe our efforts to promote sustainable behavior by our students, and provide an activity students use to track, describe, and reflect upon their personal "sustainability footprint."

\section{THE IMPORTANCE OF A CSR CURRICULUM}

People drive organizations. The innovative ideas that propel organizations to gain market shares, that drive first mover advantages, and that help to capture new and emerging markets all usually stem from a strategic plan drafted through the eyes of a visionary leader. At the same time, these organizational leaders drive the ethical and moral backbone of an organization. Hemingway and Maclagan (2004) note that a manager's personal interests and values help to shape an organization's formulation and implementation of CSR practices. Moreover, CSR practices are also linked to the attraction and retention of top talent across the globe (Bhattacharya, Sen, \& Korschun, 2008). This relationship, therefore, highlights the importance of promoting ethical and socially responsible thinking, 
decision-making, and action in the undergraduate business curriculum. Therefore, exposing students to social dilemmas, facilitating their thinking, exploring their rationale in decision making, and reflecting upon their actions, should become an integral part of the undergraduate business experience.

As a title for a course, Corporate Sustainability is too broad for the socio-economic richness of the topic area, particularly with the level of controversy and politics involved, and a semester is insufficient. A decision has to be made as to how we intend to engage our students in the content and how to promote the thinking that could cause a cultural change. Often, students reek of unjustified entitlement, senseless consumption, and ethnocentric views that can cloud ethical decisions, especially on macro-level issues. That being said, our students, our future, and their lifestyles are our problems. How do we encourage deep reflection on our global socio-economic issues while driving the importance of individual commitment towards social responsibility? A goal for this course is to open our students to their own participation to a self destructive lifestyle that effects everyone, first and third world, through data collection, analysis, research and reflection from the individual to their role and subsequent impact as a global citizen.

\section{THE PROJECT}

Unlike many other business courses, a course on sustainability grounds its foundation in our cultural norms and daily contributions to global issues. It is important to analyze the individual daily acts and how those create an impact on the global world. Therefore, such a course is well suited for course work that focuses on the lives of our students. Equally, providing students with an opportunity to reflect on one's actions outside of class is beneficial towards quantifying and understanding personal behavior, and towards initiating a paradigm shift in thinking and action. For students to relate to the topic, they must understand how their individual behaviors can impact both the micro-level behavior of others, and the macro-level decisions that have a global reach. Until recently, however, the quantification of personal behavior had been difficult to present to individual students. This was changed, however, with the work of Nicholas Felton.

Since 2005, Nicholas Felton has been tracking his personal consumption life, and he has been building super rich data sets that he makes available to the general public. Through analytics and reporting statistics, Felton illustrates and communicates a concise info-graphic that tells the story of his year, which is released as the Feltron Annual Report. His purpose, beyond the aesthetic appeal of the project, is to track his life and see how his life changes over time, with an aim to do so in a digestible, meaningful way. The Feltron Report can be likened to, and superficially resembles, a corporate annual report that tracks all levels of personal use, growth, and consumption.

The report takes weeks to create and thousands of dollars to produce, but for Felton he finds value in documenting the tiniest of memories, as they would otherwise have been lost. "It is a way of making things that are either invisible or too large to be comprehended; making them visible rather than the abstractions of looking at tables of numbers; there are pretty compelling and memorable ways of revealing invisible stories" (Mars, 2011).

In an interview for the podcast 99\% Invisible with Roman Mars (2011), Nate Berg describes Felton's project best:

It puts more focus on the little things that make up most of your time; your life isn't really that trip that you took last summer, it is the countable times that you walked down the same way to get to your office, that one house on the corner with that crazy dog, you know, how many hours of your life have you spent listening to hotel California on the radio. That is the beauty of this kind of representation. If you can take something that represents millions or even billions of actions and reduce it to something that is consumable.

A single datum may appear meaningless in the grand scope of a year; however, when that individual data point is multiplied over the course of a year, the impact can certainly change. Beyond the individual metrics, however, the Feltron Report is designed to inspire the self-reflection necessary to challenge an individual's view of the world and the world around them. Consider for a minute the following scenario. What would you do with the knowledge that over the scope of your lifetime your thirty-five minute commute would result in 113.75 days of your life spent sitting in a car? Would you get a new job? Would you consider the impact in carbon emissions and change 
your commute habits, or would you pursue the opportunity to work from home? Would you learn a new language? If according to Malcolm Gladwell the key to success in any field is a matter of practicing a specific task for a total of around 10,000 hours, then through your commute, you would be a quarter of the way there.

In the spirit of Nicholas Felton, our students are tasked with creating their own report regarding their consumption spanning a semester. The report is divided into two parts, a midterm report and final report, both of which are to be completed outside of the classroom in conjunction with course work and readings.

\section{SEMESTER SCHEDULE}

The semester is structured to inspire awareness of the issues of sustainability and corporate social responsibility through an overarching global theme. At the same time, students face the challenge of understanding their personal consumption and the impact they have as global citizens. Initially, the course relies heavily on a traditional, introductory approach to social responsibility. This is done to ensure that more complicated and controversial topics do not skew data collection. Topics post-midterm drill deeper into corporate best practices and involves activities that link organizational policy, practice, and structure to relevant world problems. As with many of discussion courses, it important to move away from a traditional text book course structure; therefore, each day involves supplementary readings that range from sustainability reports to news articles, podcasts, and videos that help to contextualize the theoretical concepts students read from the text. These readings also fuel reflective discussions where students are asked to respond to question prompts in a way that best fits the schemas they have established in preparing for class. These schemas will also be influenced by a variety of individual values, standards, and reflections of the world around them. Below are the subject areas covered over the span of the course in chronological order.

\begin{tabular}{|c|c|}
\hline $\begin{array}{l}\text { - } \text { Introduction to Sustainability and Corporate Social } \\
\text { - } \quad \text { Ovesponsibility } \\
\text { - } \quad \text { Feeding the World in } 2050 \\
\text { - } \quad \text { The Problems with Water } \\
\text { - } \quad \text { Our Addiction to Plastic } \\
\text { - } \quad \text { The Energy Crisis } \\
\text { - The Climate Crisis } \\
\text { - } \quad \text { Personal Sustainability } \\
\text { - } \quad \text { Campus Sustainability } \\
\text { - } \quad \text { Politics }\end{array}$ & $\begin{array}{ll}\text { - } & \text { Corporations } \\
\text { - } & \text { Capitalism } \\
\text { - } & \text { Human Rights } \\
\text { - } & \text { Exploitation } \\
\text { - } & \text { Respcling } \\
\text { - } & \text { Ethical Marketing } \\
\text { - } & \text { Green washing } \\
\text { - } & \text { Supply Chain Management and Manufacturing } \\
\text { - } & \text { Transportation } \\
\text { - } & \text { Human Resources and Morale }\end{array}$ \\
\hline
\end{tabular}

\section{DATA AND COLLECTION}

Data collection is largely inspired by the work of the Feltron Project; at the same time, however, the project is limited to the core of the semester. Without a year to gather data, students are expected to record 21 days worth of consumption with at least 10 data points per day, once at the beginning of the semester and then again at the end of the semester. Students are expected to record data in various categories, and in the following preferred, but not exhaustive ways. Students are also expected to research and appropriately calculate the impact of their consumption (i.e. cost of water, cost of energy, etc.), so as to make students more aware of their footprint. Beyond consumption students are expected to record data regarding either a "life event or a "life behavior" they exhibit outside of consumption of their choosing. This is used to help prompt personal reflection. 


\begin{tabular}{|c|c|}
\hline Consumption Categories & Examples \\
\hline \multirow{8}{*}{ Time spent... } & Sleeping \\
\hline & Studying \\
\hline & Eating \\
\hline & Working \\
\hline & Watching Television \\
\hline & Physically interacting with friends \\
\hline & Digitally interacting with friends \\
\hline & Traveling \\
\hline \multirow{6}{*}{ Transportation } & Associated costs \\
\hline & Time spent traveling \\
\hline & Distance traveled by public transportation \\
\hline & Distance traveled by engine \\
\hline & Distance traveled by self-propelled device \\
\hline & Distance traveled by foot \\
\hline \multirow{4}{*}{ Purchases } & Bills (Rent, Utilities, etc.) \\
\hline & Entertainment \\
\hline & Food \\
\hline & Non-essentials (Clothing, Gadgets, etc.) \\
\hline \multirow{4}{*}{ Water Consumption (Gallons and Dollars) } & Toilet \\
\hline & Showering and bathing \\
\hline & Washing Machine \\
\hline & Sink \\
\hline \multirow{7}{*}{ Energy Consumption } & Phone \\
\hline & Computer \\
\hline & Television \\
\hline & Lighting \\
\hline & Household Appliances \\
\hline & Air conditioning \\
\hline & Refrigerator \\
\hline \multirow{4}{*}{ Behavior X } & Alcohol Consumption \\
\hline & Bizarre Habits \\
\hline & Sex life \\
\hline & Caloric intake \\
\hline
\end{tabular}

Individual students collect data through a Microsoft Excel spreadsheets. This may seem archaic given the online options available on the Internet; however, spreadsheets provide students an opportunity to build, manipulate, and visualize the data that they collect. An alternative to an Excel spreadsheet is Daytum.com, a web service that allows individuals to easily record most daily activities through a variety of technological interfaces. The interaction is enhanced as it allows users to create charts and graphs that clearly illustrate the data collected. Regardless of the choice of software, there is inherent value in understanding the application of spreadsheets and their ability to visualize data for others.

Developing an appropriate medium for data collection really is dependent upon the areas of sustainability and responsibility that the individual professor would like to focus on. Finding the proper balance between the curricular needs of the course and the spirit of the assignment is an individual choice. The central tenet of the project is to provide students with an opportunity to collect meaningful, personal data that then allows them to study their personal habits and reflect upon their personal and collective impact.

\section{REFLECTION}

Beyond introducing data collection and the visualization of data, one of the principal parts of this project is to allow students to reflect on and research the impact of their personal results. The midterm and final reflective papers serve two purposes. First they enable students the opportunity to describe what the data says about their lives and their role in the community. Second, the papers allow students to extrapolate that data to make inferences about 
the impact of their current consumption patterns on the rest of their lives. Students are also asked to consider their future goals and trace their progress towards their attainment.

In addition to reflection, students are asked to research national averages for their age group and compare their lives to the national rates. Finally, the two reflective pieces are differentiated in the nation of choice: midterm results are to be compared to averages in the United States, while final results are to be compared to a nation of the student's choice, perhaps a nation of origin or one he/she would like to visit or work.

The reflective parts of the project are important in establishing an understanding of their personal practices. Students are asked to examine their data, find patterns in their use, account for resources they, perhaps, overuse, and make inferences on how their use impacts the community around them. This exercise is intended to draw student attention towards not only their personal habits, but also towards a more general view of sustainable practices as they relate to personal, and organizational use. These papers also facilitate discussions on corporate sustainability and individual global citizenship with respect to later examination of corporate sustainability reports.

\section{EXPECTED OUTCOMES}

This project is introduced in an effort to expose students to the importance of measuring and understanding their personal consumption habits. The idea is not to influence them to change the world; rather, it centers on the importance of their personal contribution to a global issue. As such, the course maintains an impact focus on how individual actions contribute to systematic processes. By tracking personal consumptions, students can understand, on a personal level, how the sum of individual parts creates greater issues.

The project is designed to generate a greater global awareness of business, sustainability, and responsibility. Naturally, the context of the course also lends itself to discussions on climate change, fair and open labor markets, paying a living wage, supply chain management, and defining what socially responsible behavior is in a foreign country.

The project is graded using a researcher-developed rubric. The rubric is designed to measure three different attribute variables. First, students are scored on a dichotomous scale on the availability of their measurements. Simply, students receive one point or zero points for capturing all of the data points on the spreadsheet. Next, students are scored on a scale of 1 to 5 on the reflective writing piece. Students are asked to be elaborative on their experience and introspective on how their consumption has an impact on the world around them. Those aspects are critical in the reflective piece as this is intended to bring the personal and the global together so that students can understand their role in a global world.

\section{CONCLUSION}

Corporate culture is often perceived to be impenetrable by new hires and inaccessible to students with little work experience. Where sustainability seeks to promote efficiency, responsible consumption and forward thinking in traditional business practices, we ought to look to ourselves as the vehicles for change. Through data and introspection we hope to develop a consciousness regarding our student's consumption that will transcend the classroom and impact the businesses they choose to work for or create for their communities.

This project forces students to examine their personal behaviors, reflect on their actions, and make decisions about what is best for them and their community. Students are also asked to examine their behaviors on a more global context - how their micro-level decisions, when compounded over the course of a lifetime, can have a measurable impact on the world around them. Further, classroom discussions can focus on the totality of impact, by examining the sum of individual habits towards a greater whole. While the scope of the project can be largely controlled by the professor, the focus should squarely be on influencing the behaviors of individuals towards ethical, moral, and sustainable behaviors. Students should be exposed to moral dilemmas, and they should try to understand the impact of those decisions and actions on governance, leadership, and responsibility. This is done to influence thinking, so that as these individuals ascend towards leadership positions, they are more adept to have a lasting impact on their organizations because of a foundation of understanding, responsibility, and moral cause. 


\section{AUTHOR INFORMATION}

Christopher N. Doval, Esq. is an Assistant Professor of Management and Marketing in the Reginald F. Lewis College of Business at Virginia State University. He teaches Business Law, Business Ethics and Corporate Sustainability. Professor Doval's research areas include business law, ethics, cyber security law, copyright and pedagogy. E-mail: cdoval@vsu.edu

Cary A. Caro, Ph.D. is an Assistant Professor of Management at Xavier University of Louisiana. He also serves as the Managing Editor for the American Journal of Business Education and the Editor in Chief for the Journal of Sustainability Management. E-mail: ccaro@xula.edu (Corresponding author)

\section{REFERENCES}

1. Bhattacharya, C. B., Sen, S., \& Korschun, D. (2008). Using corporate social responsibility to win the war for talent. MIT Sloan Management Review, 49(2), 37-44.

2. Bridges, C. M., \& Wilhelm, W. B. (2008). Going beyond green: The "why and how" of integrating sustainability into the marketing curriculum. Journal of Marketing Education, 30(1), 33-46.

3. Demoss, M., \& Nicholson, C. Y. (2005). The greening of marketing: An analysis of introductory textbooks. Journal of Education for Business, (July/August), 338-346.

4. Ethics Education in Business School. (n.d.). EETF report. Retrieved November 12, 2013 from http://www.aacsb.edu/publications/researchreports/archives/ethics-education.pdf

5. Hemingway, C. A., \& Maclagan, P. W. (2004). Managers' personal values as drivers of corporate social responsibility. Journal of Business Ethics, 50(1), 33-44.

6. Mars, R. (2011). Eposide: 31 [Radio series episode]. In 99 Percent Invisible. Internet: http://99percentinvisible.org

7. Matten, D., \& Moon, J. (2004). Corporate Social Responsibility. Journal of Business Ethics, 54(4), 323. 